\title{
DAMPAK PERTUMBUHAN EKONOMI, KONTROL KORUPSI, DAN YIELD TERHADAP INVESTASI ASING DI PASAR SUN
}

\author{
Wahyu Tri Rahmawati \\ Willem A. Makaliwe \\ wahyu3rahmawati@yahoo.com \\ Fakultas Ekonomi dan Bisnis, Universitas Indonesia
}

\begin{abstract}
Foreign investment in debt securities in Indonesia continues to grow. Foreign investor ownership in Government Securities (SUN) reached 39\% at the end of 2019 from initially only less than 1\% at the end of 2002. Foreign investor hold the largest ownership in tradable Government Securities. This study discusses the push and pull factors of foreign portfolio in debt securities investment in emerging markets and Indonesia on the period of 2000-2017. This research uses quantitative methods with panel data analysis. The results showed that economic growth, corruption control, dan financial openness were the main pull factors for foreign investment in debt instruments in emerging markets. Low yield in developed countries was the push factor of foreign investment in debt securities into emerging markets. In addition to economic growth and corruption control, yield on local debt instruments attract foreign investment in debt securities in Indonesia. The results showed that the yield on local debt securities have a negative effect on foreign investment in Indonesian debt securities so that the government does not need to provide too high yield on Government Securities.
\end{abstract}

Key words: debt securities, portofolio investment, yield

\section{ABSTRAK}

Investasi asing pada surat utang di Indonesia terus membesar. Dari hanya kurang dari 1\% pada akhir 2002, kepemilikan investor asing pada Surat Utang Negara (SUN) mencapai 39\% di akhir 2019 yang merupakan kepemilikan terbesar pada SUN yang dapat diperdagangkan. Penelitian ini membahas faktor pendorong dan penarik investasi portofolio asing pada surat utang di emerging marketss dan Indonesia pada periode 2000-2017. Penelitian ini menggunakan metode kuantitatif dengan analisis data panel. Hasil penelitian menunjukkan bahwa pertumbuhan ekonomi, kontrol korupsi, dan keterbukaan pasar finansial menjadi faktor penarik utama investasi asing pada instrumen surat utang di emerging marketss. Yield yang rendah di negara maju menjadi faktor pendorong aliran dana ke emerging markets. Selain pertumbuhan ekonomi dan kontrol korupsi, yield surat utang lokal menjadi penarik investasi asing pada surat utang di Indonesia. Hasil penelitian menunjukkan bahwa yield surat utang lokal berpengaruh negatif tehadap investasi asing di surat utang Indonesia sehingga pemerintah tidak perlu memberikan yield yang terlalu tinggi pada SUN.

Kata kunci: investasi portofolio, surat utang, yield

\section{PENDAHULUAN}

Indonesia menjadi salah satu emerging markets yang merupakan tujuan investasi menarik bagi investor asing. Emerging markets merupakan negara-negara yang telah memiliki karakteristik negara-negara yang lebih maju tetapi belum sepenuhnya memenuhi standar negara maju. Sebagai emerging markets, Indonesia menawarkan suku bunga yang lebih tinggi daripada negara-negara maju. Investasi asing terdiri dari investasi jangka pendek dan jangka panjang. Investasi jangka panjang bisa terlihat dari foreign direct investment (FDI) atau investasi asing langsung. Sedangkan foreign portfolio investment (FPI) sering 
disebut sebagai investasi asing jangka pendek karena lebih mudah bergerak.

Perbedaan antara FDI dan FPI adalah bahwa investor FPI tidak menginginkan pengendalian atau pengelolaan secara aktif di perusahaan yang menerbitkan obligasi dan saham (Tsaurai, 2017; Musibau et al., 2019). Bagi investor, FPI memiliki lebih sedikit risiko karena tidak perlu mengelola langsung perusahaan tujuan. Investor FPI juga lebih mudah menjual aset daripada FDI. Sebaliknya, bagi negara tujuan, FPI kurang stabil jika dibandingkan dengan FDI karena kemudahan penarikan dana ke negara asal.

Di Indonesia, FPI mengalir di pasar saham dan pasar obligasi atau surat utang. Investasi asing di surat utang di Indonesia terutama pada Surat Utang Negara (SUN). SUN adalah instrumen surat utang yang diterbitkan oleh pemerintah untuk membiayai anggaran dan belanja negara.

Total nilai SUN rupiah yang dapat diperdagang-kan mencapai $\mathrm{Rp} 2.753$ triliun pada akhir 2019. Dari total SUN dengan mata uang rupiah yang dapat diperdagangkan, kepe-milikan asing mencapai Rp 1.062 triliun atau sekitar 39\%, melonjak dari hanya $0,48 \%$ pada akhir tahun 2002. Persentase kepemilikan asing terhadap total SUN ini jauh lebih tinggi jika dibandingkan dengan Malaysia yang sekitar 29\%. Meski terus tumbuh, Indonesia memiliki ukuran pasar surat utang yang relatif kecil jika diban-dingkan dengan total ekonomi. Dengan ukuran pasar obligasi Indonesia yang masih relatif kecil, pergerakan dana asing pada instrumen SUN bisa memengaruhi harga dan yield SUN di pasar sekunder di Bursa Efek Indonesia (BEI). Dari sisi nilai outstanding surat utang, SUN mendominasi pasar obligasi hingga $86,11 \%$. Transaksi ber-bagai jenis obligasi negara mencapai $94,67 \%$ dari total transaksi instrumen surat utang yang tercatat di BEI.

Investor asing memburu SUN karena menawarkan imbal hasil yang lebih tinggi jika dibandingkan dengan surat utang negara-negara kawasan Asia Tenggara. Yield surat utang menunjukkan tingkat pengembalian hasil atau suku bunga yang diberikan negara tersebut. Yield ini juga menunjukkan kisaran suku bunga yang dibayarkan negara tersebut untuk menerbitkan surat utang baru.

Semakin tinggi yield, maka semakin besar bunga atau beban yang harus dibayar negara jika menerbitkan surat utang. Dari sisi investor, semakin tinggi yield, keuntungan penempatan inves-tasi di negara tersebut akan makin besar. Tabel 1 menunjukkan yield obligasi negara dengan tenor 10 tahun dalam mata uang lokal negara-negara di Asia Tenggara, diurutkan berdasarkan peringkat tertinggi.

Tabel 1

Yield dan Peringkat Utang Obligasi Enam Negara ASEAN

\begin{tabular}{lcll}
\hline \multirow{2}{*}{ Negara } & $\begin{array}{c}\text { Yield 10 Tahun } \\
(\mathbf{2 0 1 9 )}\end{array}$ & \multicolumn{2}{c}{ Peringkat Utang } \\
\cline { 3 - 4 } & & \multicolumn{1}{c}{ Fitch } & \multicolumn{1}{c}{ S\&P } \\
\hline Singapura & $1,73 \%$ & AAA & AAA \\
Malaysia & $3,31 \%$ & A- & A- \\
Thailand & $1,47 \%$ & BBB+ & BBB+ \\
Filipina & $4,34 \%$ & BBB & BBB+ \\
Indonesia & $7,03 \%$ & BBB & BBB \\
Vietnam & $3,42 \%$ & BB & - \\
\hline
\end{tabular}

Sumber: Bloomberg, Fitch Ratings, S\&P, diolah (2020). 
Meski berada pada peringkat yang sama, Filipina memiliki yield yang jauh lebih rendah daripada Indonesia. Bahkan, Vietnam dengan peringkat non-investment grade dan lebih rendah daripada Indonesia, yakni BB, memiliki yield surat utang yang lebih rendah daripada Indonesia dan Filipina. Yield surat utang Vietnam ini jauh menurun dalam lima tahun terakhir. Pada akhir 2014, yield surat utang Vietnam bertenor 10 tahun masih berada di angka $7,51 \%$. Sedangkan yield rata-rata dalam lima tahun terakhir Vietnam sebesar 5,87\%.

SUN adalah surat berharga yang berupa surat pengakuan utang dalam mata uang rupiah maupun valuta asing yang dijamin pembayaran bunga dan pokoknya oleh Negara Republik Indonesia, sesuai dengan masa berlakunya. Surat utang pertama Indonesia terbit setelah proklamasi kemerdekaan. Pada tahun 1946, pemerintah menerbitkan Obligasi Nasional Republik Indonesia. Surat utang ini memiliki jangka waktu 40 tahun. Pemerintah menggunakan dana hasil penerbitan obligasi nasional ini untuk membiayai sektor pertanian dan kerajinan rakyat. Tapi, defisit di awal dekade 1950 menyebabkan pemerintah menurunkan nilai uang dan menyimpan sebagian dalam obligasi negara 1950 dan sebagian lain digunakan sebagai alat pembayaran. Setelah itu, pemerintah menerbitkan dua obligasi tahun 1959, yakni Obligasi Konsolidasi 1959 dan Obligasi Berhadiah 1959. Tapi, banyak pemilik obligasi tidak bisa mencairkan obligasi karena pencatatan yang tidak jelas.

Pemerintah baru menerbitkan lagi SUN pada tahun 2002 setelah adanya landasan hukum Undang-Undang (UU) Nomor 24 Tahun 2002 tentang Surat Utang Negara. Pemerintah menerbitkan SUN terutama untuk rekapitalisasi perbankan pascakrisis ekonomi Indonesia yang dimulai tahun 1997-1998. Dari total SUN yang dapat diperdagangkan senilai Rp 394,06 triliun per akhir tahun 2002, sebesar Rp 348,40 triliun atau $88,41 \%$ SUN dimiliki oleh perbankan. Saat itu, kepemilikan asing pada SUN hanya sebesar Rp 1,91 triliun atau 0,48\% dari total SUN yang dapat diperdagangkan.

Setelah tahun 2002, SUN menjadi salah satu sumber pendanaan APBN yang rutin. Dari awalnya sebesar Rp 394,06 triliun, total SUN yang dapat diperdagangkan menjadi Rp 2.752,74 triliun pada akhir Desember 2019. SUN dan pengelolaannya diatur dalam UU Nomor 24 Tahun 2002 tentang Surat Utang Negara. Berdasarkan UU Nomor 24 Tahun 2002, penerbitan SUN dilakukan hanya untuk tujuan-tujuan tertentu. Pemerintah wajib membayar bunga dan pokok SUN yang jatuh tempo. Jumlah SUN yang akan diterbitkan setiap tahun anggaran harus memperoleh persetujuan Dewan Perwakilan Rakyat (DPR) dan dikonsultasikan terlebih dahulu dengan Bank Indonesia (BI). Perdagangan SUN diatur dan diawasi oleh instansi yang berwenang. UU Nomor 24 Tahun 2002 juga memberikan sanksi hukum yang berat dan jelas terhadap penerbitan oleh pihak yang tidak berwenang dan/atau pemalsuan SUN.

Tabel 2 Kepemilikan SUN

\begin{tabular}{lrr}
\hline \multirow{2}{*}{\multicolumn{1}{c}{ Investor }} & \multicolumn{2}{c}{ Desember $\mathbf{2 0 1 9}$} \\
\cline { 2 - 3 } & \multicolumn{1}{c}{ Nilai } & \multicolumn{1}{c}{$\%$} \\
\hline Bank & 581,37 & $21,12 \%$ \\
Bank Indonesia & 262,49 & $9,54 \%$ \\
Reksadana & 130,86 & $4,75 \%$ \\
Asuransi & 215,01 & $7,81 \%$ \\
Asing & $1.061,86$ & $38,57 \%$ \\
Dana Pensiun & 256,66 & $9,32 \%$ \\
Individu & 81,18 & $2,95 \%$ \\
Lain-lain & 163,32 & $5,93 \%$ \\
\hline Total & $\mathbf{2 . 7 5 2 , 7 4}$ & $\mathbf{1 0 0} \%$ \\
\hline
\end{tabular}

Sumber: DJPPR Kementerian Keuangan, nilai dalam triliun rupiah (2020)

Pada tabel 2 menunjukkan kepemilikan SUN pada tahun 2020. Pada saat ini, kepemilikan SUN sudah terdistribusi lebih luas daripada tahun 2002. Tapi jika dilihat, porsi terbesar kepemilikan SUN adalah 
investor asing, disusul perbankan, Bank Indonesia, dan dana pensiun. Porsi kepemilikan asing pada SUN di akhir Desember 2019 sudah mencapai 38,57\% dengan total nilai $\mathrm{Rp} 1.061,86$ triliun. Kepemilikan asing pada SUN di Indonesia ini terhitung besar jika dibandingkan dengan negara-negara Asia. Dengan ukuran pasar obligasi Indonesia yang masih relatif kecil, pergerakan dana asing pada instrumen SUN akan sangat memengaruhi harga dan yield SUN di pasar sekunder.

SUN yang dapat diperdagangkan tersebut ditransaksikan di pasar sekunder pada Bursa Efek Indonesia (BEI). Perdagangan SUN dan berbagai surat utang, termasuk obligasi korporasi dan sukuk, dilakukan terutama di luar bursa atau over the counter. Lewat perdagangan over the counter, pihak penjual dan pembeli menyepakati harga tanpa melalui platform langsung di bursa. Setelah terjadi transaksi, kedua pihak melaporkan transaksi tersebut ke BEI untuk dicatatkan. BEI sedang mengembangkan platform untuk transaksi online surat utang seperti halnya perdagangan saham. Dengan pengem-bangan ini, transaksi surat utang akan berlangsung real time seperti perdagangan saham.

Menurut data BEI, total efek atau surat berharga pemerintah yang tercatat hingga akhir Desember 2019 mencapai Rp 2.752,74 triliun, terdiri dari SUN dengan suku bunga tetap dan suku bunga mengambang, Obligasi Negara Ritel (ORI), Surat Perbendaharaan Negara (SPN), Sukuk Negara, Sukuk Ritel, Project Based Sukuk (PBS), dan SPN Syariah. Selain obligasi negara, BEI pun mencatat total surat utang korporasi, baik obligasi konvensional maupun sukuk dengan total nilai Rp 445,10 miliar. SUN mendominasi nilai outstanding surat utang hingga $86,11 \%$.

Data BEI menunjukkan bahwa nilai transaksi harian surat utang atau obligasi, baik itu obligasi negara maupun obligasi korporasi, mencapai Rp 28,95 triliun per hari. Nilai transaksi obligasi ini lebih besar daripada nilai transaksi saham yang sebesar
Rp 8,14 triliun per hari. Padahal, nilai kapitalisasi pasar saham yang menunjukkan total nilai seluruh saham perusahaan tercatat di BEI mencapai Rp 7.265,01 triliun. Nilai transaksi obligasi lebih besar karena nilai transaksi per frekuensi transaksi obligasi lebih besar daripada nilai per frekuensi transaksi saham. Transaksi obligasi negara mencapai $94,67 \%$ dari total transaksi instrumen seluruh jenis surat utang yang tercatat di BEI.

Kontribusi penelitian ini adalah untuk memperkaya literatur penelitian tentang aliran modal asing di pasar keuangan Indonesia, terutama di pasar SUN. Selain meneliti pengaruh yield, penulis melihat variabel lain seperti keterbukaan pasar finansial, kontrol korupsi yang merupakan proxy institution dan rata-rata lama tahun pendidikan yang merupakan proxy human capital. Aliran dana asing yang tinggi pada pasar SUN Indonesia membawa keuntungan karena pemerintah mendapatkan dana untuk membiayai APBN. Di sisi lain, kepemilikan asing yang besar bisa mengguncangkan pasar keuangan jika ada penarikan dana besar-besaran mengingat likuiditas SUN yang tinggi. Untuk itu, perlu dicermati faktor-faktor yang bisa memengaruhi aliran dana asing di pasar surat utang Indonesia.

Penelitian ini bertujuan untuk menentukan faktor-faktor yang memengaruhi aliran modal asing ke instrumen Surat Utang Negara di Indonesia. Penelitian tidak hanya melihat variabel di Indonesia, tetapi juga emerging markets sehingga bisa memberikan gambaran lebih lengkap mengenai aliran investasi portofolio ke instrumen surat utang Indonesia yang termasuk dalam kategori emerging markets.

\section{TINJAUAN TEORETIS}

Dalam menentukan pembelian aset berupa obligasi, investor akan mempertimbangkan empat hal, yaitu kekayaan yang dimiliki, return yang diharapkan, risiko, serta likuiditas aset. Empat faktor yang menentukan permintaan aset ini merupakan 
theory of asset demand atau teori permintaan aset (Mishkin, 2019). Semakin tinggi kekayaan maka jumlah aset yang diminta semakin banyak. Return tidak hanya mempertimbangkan tingkat pengembalian (yield) dari aset tersebut, tapi juga tingkat pengembalian aset lain. Jika return aset tersebut meningkat secara relatif jika dibandingkan dengan aset lain, maka jumlah yang diminta pada aset tersebut meningkat. Jika risiko suatu aset atau instrumen investasi naik relatif terhadap aset alternatif yang lain, maka jumlah yang diminta pada aset tersebut turun. Likuiditas merupakan kemudahan dan kecepatan aset tersebut dicairkan menjadi uang tunai dibandingkan dengan aset lain. Semakin mudah aset dicairkan, semakin tinggi jumlah aset yang diminta.

Berdasarkan teori permintaan aset, investor asing akan menempatkan dana pada instrumen surat utang emerging markets dengan mempertimbangkan return, risiko, dan likuiditas aset. Return surat utang emerging markets paling mudah dilihat dari yield atau imbal hasil dibandingkan dengan return instrumen investasi lain atau yield surat utang di negara lain. Risiko bisa dilihat mulai dari kondisi ekonomi makro negara tujuan, stabilitas ekonomi atau politik negara tersebut, serta kondisi ekonomi global secara keseluruhan. Sedangkan likuiditas aset yang merupakan kemudahan menarik investasi bisa dilihat dari keterbukaan pasar finansial, rezim nilai tukar, serta ada atau tidaknya campur tangan otoritas terhadap pasar finansial.

Untuk menilai besaran risiko suatu obligasi jika dibandingkan dengan aset aman seperti obligasi negara Amerika Serikat (AS), US Treasury Bond, ada lembaga pemeringkat yang menentukan level risiko penerbit obligasi. Lembaga pemeringkat menyediakan informasi level risiko penerbit obligasi melalui rating mulai dari level tertinggi dengan hampir tanpa risiko gagal bayar hingga level terendah dengan risiko gagal bayar tinggi. Pelaku pasar keuangan menyebut risiko gagal bayar minimal dengan investment grade dan risiko gagal bayar tinggi atau speculative grade.

Istilah investmet grade dan speculative grade merupakan konvensi pasar keuangan dan tidak mengimplikasikan rekomendasi pada surat berharga tertentu untuk tujuan investasi (Patrino, 2020). Lembaga keuangan internasional biasanya menetapkan pilihan pada aset dengan kriteria investment grade sebelum memilih obligasi negara. Peringkat negara (sovereign rating) berkontribusi pada peningkatan arus modal antar negara dalam beberapa dekade terakhir, terutama pada investasi portofolio asing. Khususnya sebelum 2008, kualitas peringkat negara tujuan memicu investasi portofolio yang lebih tinggi (Körner dan Trautwein, 2015).

Selain lembaga pemeringkat, pasar keuangan mengenal Sovereign Credit Default Swap (SCDS). SCDS mengukur risiko kredit negara. SCDS juga dianggap sebagai premi risiko negara penerbit surat utang. Semakin tinggi SCDS suatu negara, maka semakin tinggi risiko negara tersebut. Investor dan lembaga keuangan internasional perlu lebih fokus pada SCDS negara berkembang yang memiliki peran penting dalam transmisi guncangan daripada di negara-negara yang berada di pusat krisis (Bostanci dan Yilmaz, 2020).

Aliran investasi ke emerging markets dipengaruhi oleh adanya krisis finansial yang juga merupakan faktor risiko secara global. Pengaruh ini terlihat pada lonjakan arus masuk serta pembalikan investasi asing di emerging markets. Arus investasi masuk di emerging markets naik signifikan karena perubahan suku bunga riil AS dan risk aversion atau penghindaran risiko. Pembalikan arus investasi dari emerging markets bisa terjadi juga karena peran perubahan suku bunga AS dan pengalihan risiko. Emerging markets dengan pasar keuangan yang lebih berkembang juga lebih rentan terhadap pembalikan (Qureshi dan Sugawara, 2018).

Ketidakpastian global meningkatkan kemungkinan kontraksi investasi portofolio 
baik di negara maju maupun negara berkembang. Kondisi ketidakpastian tersebut justru meningkatkan investasi langsung atau FDI hanya di negara maju. Hal ini menunjukkan bahwa FDI lebih tangguh di negara berkembang pada masa ketidakpastian global yang tinggi. Tetapi, analisis menunjukkan bahwa FDI rentan terhadap guncangan ketidakpastian di negara maju (Hlaing dan Kakinaka, 2019).

Internasionalisasi pasar finansial yang membuka peluang bagi investor asing untuk berinvestasi di suatu negara tidak hanya menghasilkan keuntungan bagi investor tetapi juga negara yang dituju. Misalnya saja, Jepang dan China merupakan negara dengan pemegang obligasi negara AS terbesar. Kedua negara ini menyediakan pendanaan ke AS dan membantu pendanaan pemerintah AS. Tanpa dana asing ini ekonomi AS akan tumbuh jauh lebih rendah (Mishkin, 2019). Peningkatan pasokan US Treasury kemungkinan akan menarik lebih banyak investasi dari luar AS. Tapi, efek tersebut merupakan efek kedua setelah suku bunga. Investasi asing pada US Treasury dipengaruhi oleh tingkat suku bunga negara asal yang cenderung rendah (Ammer et al., 2019).

Investor asing ini tidak selalu negara yang memiliki surplus dana tapi juga investor institusi seperti pengelola dana (fund manager), private equity, dana pensiun, atau pemodal asing yang mencari alternatif investasi di luar negara asal mereka. Salah satu alasan investor mencari alternatif instrumen investasi lintas negara adalah diversifikasi. Diversifikasi merupakan hal yang sudah diamati dan masuk akal untuk dilakukan (Markowitz, 1952). Dengan diversifikasi, investor menyeimbangkan antara instrumen efek dengan imbal hasil rendah berisiko kecil seperti investasi di negara maju dan efek dengan imbal hasil tinggi dengan risiko yang lebih besar di emerging markets. Risiko ini sudah termasuk di dalam expected return atau imbal hasil yang diharapkan. Pada dunia investasi dikenal high risk, high return. Artinya, investasi yang memiliki return atau tingkat pengembalian tinggi juga memiliki risiko yang tinggi.

Keterbukaan finansial dan keterbukaan perdagangan suatu negara akan memengaruhi aliran masuk investasi asing. Faktor lain yang turut meningkatkan aliran dana investasi asing antara lain cadangan devisa, utang publik, pertumbuhan ekonomi, infrastruktur, kontrol modal, serta premi risiko yang ditawarkan suatu negara pada instrumen surat utang (Byrne dan Fiess, 2016; Cerutti et al., 2019; Kinda, 2012; Sanya dan Olanrewaju, 2015). Premi risiko pada utang negara yang ditunjukkan dengan spread atau selisih dengan yield utang negara maju, ditentukan oleh aggregate risk, kepemilikan asing pada surat utang, ekspektasi inflasi, serta faktor likuiditas global (Ebeke dan Lu, 2015; Konopczak dan Konopczak, 2017; Yun, 2019). Sementara aliran dana asing ke pasar modal dan obligasi domestik akan memengaruhi partumbuhan ekonomi, bisa meningkatkan harga surat utang negara, meningkatkan likuiditas pasar SUN, dan menaikkan nilai tukar (Musibau et al., 2019; Pandolfi dan Williams, 2019; Tsaurai, 2017).

Pergerakan investasi internasional bisa terjadi karena dua faktor, yakni faktor pendorong dari eksternal dan faktor penarik dari domestik suatu negara. Suku bunga internasional dan tingkat partumbuhan ekonomi dunia menjadi faktor pendorong dari luar. Meski fundamental ekonomi domestik bisa memicu aliran modal yang lebih besar, kekuatan ekonomi domestik ini tidak bisa memastikan bahwa suatu negara kebal dari pengaruh pergerakan modal internasional misalnya karena krisis finansial global. Oleh karena itu, suatu negara perlu memonitor basis investor seperti pengelola dana dan perbankan global untuk menjaga stabilitas finansial (Cerutti et al., 2019).

Hedge fund yang merupakan salah satu pengelola dana adalah partisipan pasar penting. Hedge fund lebih memilih surat utang jangka panjang yang menawarkan 
yield lebih besar daripada surat utang jangka pendek. Aliran dana dari hedge fund bisa memprediksikan perubahan yield obligasi (Kolokolova et al., 2020).

Perubahan kebijakan moneter negara maju juga menjadi faktor pendorong investasi ke emerging markets. Bukti dampak ini terlihat pada saat krisis finansial global sekitar tahun 2008. AS mengeluarkan kebijakan suku bunga sangat rendah untuk mengatasi krisis. Aliran dana langsung FDI dan portofolio FPI berubah pada periode sebelum dan sesudah krisis. Setelah keputusan suku bunga bank sentral AS Federal Reserve, aliran dana FPI naik dengan pesat sementara FDI meningkat tipis. Hal ini menunjukkan bahwa perubahan kebijakan AS lebih memengaruhi FPI daripada FDI (Olani, 2020).

Sejak tahun 2000, faktor global yang berada di luar kendali emerging markets menjadi semakin signifikan sebagai pendorong aliran dana jika dibandingkan dengan faktor domestik. Tetapi, beberapa faktor makroekonomi dan keuangan domestik mampu mengurangi volatilitas aliran modal tertentu. Faktor makroekonomi domestik memiliki dampak berbeda untuk beberapa jenis aliran dana investasi. Faktor domestik sangat berpengaruh pada volatilitas FDI dan dana perbankan tapi tidak pada investasi portofolio (Broto et al., 2011).

Faktor global yang memengaruhi aliran modal antara lain yield obligasi jangka panjang di negara maju. Penurunan yield jangka panjang pada US Treasury akan mendorong aliran dana investor ke emerging markets (Byrne dan Fiess, 2016). Lebih dari $80 \%$ variasi arus obligasi dan ekuitas disebabkan oleh faktor pendorong dari AS ke negara lain. Oleh karena itu, kekuatan ekonomi global menguasai kekuatan ekonomi domestik dalam menjelaskan pergerakan arus portofolio internasional (Sarno et al., 2016).

Selisih atau perbedaan pertumbuhan, perbedaan tingkat suku bunga, dan penghindaran risiko global merupakan pendorong penting aliran bersih modal ke emerging markets. Selisih suku bunga menjadi lebih penting pada periode pascakrisis. Perbedaan pertumbuhan ekonomi selalu menjadi determinan kunci untuk total aliran dana ke emerging markets, tetapi tidak untuk aliran investasi portofolio (Ahmed dan Zlate, 2014).

Pada kasus India, nilai tukar dengan volatilitas yang lebih rendah serta peluang diversifikasi di negara lain yang lebih berisiko menyebabkan peningkatan aliran dana asing. Jika imbal hasil investasi saham di negara emerging markets lain meningkat, maka aliran dana portofolio asing ke India akan berkurang (Garg dan Dua, 2014). Yield yang tinggi belum tentu menjadi daya tarik bagi investor asing. Tingginya premi risiko, yaitu selisih suku bunga domestik dengan suku bunga asing yang dianggap berisiko rendah, menunjukkan bahwa yield obligasi negara yang ditawarkan pun tinggi. Premi risiko dan yield obligasi yang tinggi berdampak negatif terhadap pembentukan modal tetap bruto Nigeria (Sanya dan Olanrewaju, 2015).

Sebaliknya, aliran dana ke emerging markets memengaruhi pergerakan yield pada pasar domestik. Investor asing bisa menjadi sumber permintaan terbesar surat utang lokal yang meningkatkan harga dan menurunkan yield (Yun, 2019; Ebeke dan Lu, 2015). Investasi asing ini juga memiliki efek tumpahan terhadap nilai tukar domestik (Pandolfi dan Williams, 2019). Meski bisa menurunkan yield karena adanya kenaikan permintaan dan harga, aliran dana asing ke pasar keuangan domestik ini bisa meningkatkan volatilitas yield. Pasar obligesi yang membesar dengan adanya investor asing menyebabkan transaksi juga meningkat sehingga yield menjadi lebih volatile seiring pergerakan harga. Volatilitas terutama terjadi pada negara-negara dengan posisi fiskal yang lemah (Ebeke dan Lu, 2015).

Dampak kepemilikan asing terhadap spread atau selisih yield obligasi berbeda antara satu negara dengan negara lain. Pada kasus Rusia, kenaikan 1\% kepemilikan 
asing menurunkan spread 16 basis points. Pada kasus Indonesia, kenaikan 1\% kepemilikan asing menaikkan spread 46 basis points (Konopczak dan Konopczak, 2017). Kondisi berbeda terjadi pada obligasi negara AS. Aliran dana asing menurunkan yield US Treasury, baik dalam jangka pendek maupun jangka panjang (Beltran et al., 2013).

Penegasan efek aliran dana asing terhadap yield lebih tampak di China. Penelitian Pham atas yield obligasi negara China periode 1994-2012 menunjukkan bahwa biaya pendanaan atau bunga yang harus dibayar pemerintah China tidak bergantung pada kondisi fundamental makroekonomi. Satu-satunya variabel dari delapan variabel yang signifikan berpengaruh pada yield obligasi negara China adalah partisipasi investor asing (Pham, 2015). Dari faktor domestik, inflasi, kebijakan suku bunga, dan indikator persepsi risiko merupakan variabel yang paling memengaruhi kecuraman kurva yield (Melo-Becerra et al., 2015).

Aliran dana investor asing juga berpengaruh pada nilai tukar. Nilai tukar rupiah memiliki pengaruh timbal balik terhadap aliran investasi di pasar obligasi Indonesia. Partisipasi asing di pasar obligasi Indonesia lebih berpengaruh terhadap nilai tukar daripada partisipasi asing di pasar saham (Anggitawati dan Ekaputra, 2018). Hubungan volatilitas nilai tukar dan aliran investasi asing di emerging markets menunjukkan bahwa dampak langsung dari aliran investasi asing di pasar saham dan obligasi terhadap volatilitas nilai tukar di tujuh emerging markets Asia berbeda-beda untuk setiap negara (Caporale et al., 2017).

Perbedaan dampak pada penelitian di Asia tersebut juga terjadi di Afrika. Dalam kasus Afrika, aliran investasi portofolio internasional relatif volatile dan tergantung pada negara tujuan investasi. Hubungan dinamis antara aliran investasi portofolio dan nilai tukar mata uang saling ketergantungan dan bervariasi. Selisih suku bunga antara Mesir dan AS memiliki penga- ruh penting pada nilai tukar di Mesir tetapi tidak berlaku demikian untuk negara seperti Maroko dan Afrika Selatan (Kodongo dan Ojah, 2012).

Dampak investasi portofolio terhadap penguatan nilai tukar mata uang lebih kuat daripada investasi langsung atau kredit perbankan. Tetapi, upaya otoritas keuangan dan bank sentral untuk menahan penguatan nilai tukar tidak mampu menghindari penguatan riil nilai tukar. Memberikan fleksibilitas nilai tukar justru bisa menetralisir penguatan dari aliran dana masuk dan menghindari hilangnya daya saing negara tersebut (Combes et al., 2012). Stabilisasi nilai tukar yang menjadi kebijakan moneter penting bank sentral Indonesia untuk memperkuat kepercayaan investor dan menjaga stabilitas inflasi hanya mencapai keberhasilan terbatas untuk memoderasi fluktuasi aliran modal, inflasi, dan volatilitas nilai tukar (Jayasuriya dan Leu, 2017). Dalam kondisi ekonomi yang stabil, kebijakan nilai tukar fleksibel lebih unggul daripada rezim nilai tukar tetap. Sebaliknya ketika terjadi guncangan positif maupun negatif, rezim nilai tukar tetap menghasilkan kesejahteraan yang lebih tinggi daripada nilai tukar fleksibel (Kitano dan Takaku, 2018).

Ketidakstabilan nilai tukar bisa mengurangi arus masuk dana ke emerging markets. Tetapi dampak tidak langsung volatilitas nilai tukar yang terjadi karena perkembangan finansial justru positif. Hal ini menunjukkan bahwa perkembangan finansial mengurangi dampak buruk dari ketidakstabilan nilai tukar terhadap arus modal masuk (Jehan dan Hamid, 2017). Perkembangan finansial ini juga penting dalam menghadapi aliran dana asing yang masuk. Manfaat positif dari aliran masuk modal hanya ditemukan pada negaranegara dengan perkembangan pasar keuangan yang lebih dari ambang batas (Baharumshah et al., 2017).

Meski faktor pendorong investasi secara global berpengaruh pada aliran modal ke emerging markets, faktor penarik investasi berupa kualitas negara tujuan 
tetap penting mengingat bahwa yield yang tinggi di suatu negara belum tentu menyebabkan investasi portofolio di negara tersebut menarik. Yield yang tinggi selalu diikuti dengan risiko yang tinggi juga. Pertumbuhan Produk Domestik Bruto (PDB) menjadi fitur penting dalam menjelaskan aliran modal portofolio. PDB bisa menjadi proxy untuk potensi pasar yang menjadikan perusahaan-perusahaan di negara tujuan lebih menguntungkan. PDB sebagai indikator aliran dana asing ini bisa diinterpretasikan bahwa negara-negara G7 menginvestasikan dana ke negara-negara lebih kaya daripada negara yang lebih miskin (Vo et al., 2017).

Faktor karakteristik atau kualitas negara menjadi pertimbangan dalam penempatan dana oleh investor asing. Karakteristik berupa keterbukaan finansial suatu negara menjadi satu variabel yang banyak dibahas dalam berbagai literatur. Keterbukaan finansial juga sering dikaitkan dengan kontrol modal (capital control). Kontrol modal ini tetap dilakukan meski pada rezim nilai tukar fleksibel. Pada rezim nilai tukar fleksibel, kontrol modal bisa menavigasi dengan lebih baik tujuan stabilisasi makroekonomi (Farhi dan Werning, 2014).

Emerging markets menghadapi volatilitas tinggi dalam arus modal masuk dan keluar. Negara-negara lebih melonggar-kan arus keluar sebagai respons penguatan nilai tukar dan untuk menghindari overheating. Tetapi, negara lebih membatasi arus modal keluar jika menghadapi kekhawatiran stabilitas finansial atau volatilitas makroekonomi (Aizenman dan Pasricha, 2013). Kontrol modal pada level tertentu bisa memuluskan fluktuasi pasar karena hot money dan menguntungkan keberaan pasar finansial lokal dan ekonomi emerging markets (Yan, 2018).

Faktor human capital menjadi sorotan pada aliran dana asing ke suatu negara. Negara-negara kaya justru mendapatkan aliran modal lebih besar daripada negaranegara miskin yang dikenal sebagai Lucas
Paradox. Risiko politik merupakan faktor penting yang membatasi aliran modal internasional sehingga negara yang lebih miskin belum tentu mendapatkan aliran dana lebih besar daripada negara-negara lebih kaya (Lucas, 1990). Negara-negara dengan human capital rendah memiliki produktivitas tenaga kerja lebih rendah daripada negara dengan human capital tinggi. Artinya, produksi atau output negara dengan human capital rendah juga lebih rendah. Human capital mewakili kualitas sumber daya manusia di suatu negara yang dilihat dari sisi tingkat pendidikan (Mankiw, 2013). Perbaikan kebijakan terkait human capital bisa berpengaruh pada keterbukaan terhadap investasi asing (Kinda, 2012).

Faktor institution atau kelembagaan termasuk faktor penarik investasi suatu negara. Faktor kelembagaan ini termasuk antara lain penegakan hukum, tingkat korupsi, dan stabilitas politik (Mankiw, 2013). Jika kelembagaan suatu negara buruk, maka dana asing baik itu FDI maupun FPI enggan masuk meski keterbukaan finansial negara tersebut positif. Keterbukaan finansial dan kualitas kelembagaan secara individu tidak berdampak signifikan terhadap pergerakan aliran modal internasional (Okada, 2013). Menurut penelitian Okada, efek parsial keterbukaan finansial meningkatkan kualitas kelembagaan. Keterbukaan finansial akan lebih menguntungkan negara-negara dengan kualitas kelembagaan yang lebih baik.

Korupsi juga termasuk dalam faktor kelembagaan yang bisa menentukan aliran dana asing. Negara dengan kontrol korupsi yang baik akan memiliki aliran investasi yang lebih besar. Selain itu, kontrol korupsi yang lebih tinggi bisa memperbesar aliran investasi dari negara-negara dengan level korupsi yang rendah sehingga meningkatkan kelembagaan ekonomi dan politik negara tujuan (Belgibayeva dan Plekhanov, 2019). Jika suatu negara belum memiliki investasi asing yang signifikan, mengurangi korupsi berpotensi meningkatkan investasi 
perusahaan multinasional di negara tersebut (Yi et al., 2019).

Negara dengan tingkat korupsi yang sangat tinggi menarik investasi portofolio lebih besar daripada negara dengan tingkat korupsi moderat. Ini terjadi dengan asumsi bahwa pada tingkat korupsi tinggi, telah diketahui pihak-pihak yang terkait korupsi atau lebih terbuka daripada tingkat korupsi moderat. Investor tetap masuk pada investasi negara dengan tingkat korupsi tinggi karena ada informasi yang lebih terbuka. Dengan kondisi ini, asimetri informasi pada negara dengan korupsi tinggi justru lebih rendah daripada negara dengan tingkat korupsi moderat (Jain et al., 2017). Dana dari investor lokal akan lebih mendapatkan keuntungan di negara-negara dengan asimetri informasi yang lebih tinggi, negara-negara yang tidak berbahasa Inggris, dan negara-negara dengan pasar keuangan yang kurang efisien, perlindungan investor yang buruk, atau tingkat korupsi yang buruk daripada investor asing (Ferreira et al., 2017).

\section{METODE PENELITIAN}

Penelitian ini menggunakan metode analisis data panel dengan fixed effect model. Pemilihan fixed effect model berdasarkan uji statistik yang dilakukan dalam penelitian. Metode data panel pada penelitian tentang aliran investasi portfolio pada instrumen surat utang dipilih untuk melihat gambaran aliran investasi ke surat utang secara umum di emerging markets sebelum melihat secara khusus untuk Indonesia. Dengan melihat gambaran kondisi emerging markets, penulis berharap hasil penelitian terhadap instrumen surat utang Indonesia menjadi lebih komprehensif. Penelitian ini mengadaptasi model Byrne dan Fiess (2016) dengan perbedaan proxy variabel. Model yang digunakan adalah:

$$
\begin{aligned}
\operatorname{Cap}_{i t}=\alpha_{0}+ & \alpha_{1} F_{i t}+\alpha_{2} I_{i t}+\alpha_{3} H C_{i t} \\
& +\alpha_{4} \Delta Y_{i t}+\alpha_{5} R_{i t}+\alpha_{6} C P_{. t} \\
& +\alpha_{7} \operatorname{RSRUS}_{. t}+\alpha_{8} R_{L R U S} S_{. t} \\
& +\alpha_{9} V I X_{. t}+\alpha_{10} \Delta Y_{. t}^{G 7}+\varepsilon_{i t}
\end{aligned}
$$

Persamaan tersebut menunjukkan aliran dana masuk (Capit) untuk negara I pada waktu t, merupakan fungsi karakteristik keterbukaan finansial atau financial openness $\left(\mathrm{FO}_{\mathrm{it}}\right)$, institution $\left(\mathrm{I}_{\mathrm{it}}\right)$, human capital $\left(\mathrm{HC}_{\mathrm{it}}\right)$. Sisanya merupakan faktor determinan penarik dari suatu negara dalam bentuk pertumbuhan PDB negara tersebut $\left(\Delta \mathrm{Y}_{\mathrm{it}}\right)$ dan suku bunga lokal $\left(\mathrm{R}_{\mathrm{it}}\right)$. Aliran dana masuk juga dipengaruhi oleh determinan global termasuk harga komoditas $\left(\mathrm{CP}_{\mathrm{t}}\right)$, suku bunga riil short term AS (RSRUS.t), dan suku bunga AS jangka panjang (RLRUS.t), indeks volatilitas VIX (VIX.t), dan pertumbuhan PDB riil negara G7 $\left(\Delta Y_{. t} G 7\right)$. Pernyataan (.t) menunjukkan bahwa faktor ini merupakan faktor global dan tidak berubah di seluruh cross section. Parameter $\mathrm{a}_{0}$ dan $\mathrm{a}_{10}$ merupakan koefisien estimasi panel dan $\varepsilon$ merupakan error term.

Penelitian menggunakan fixed effect model karena sampel negara tidak diambil secara acak. Fixed effect model mengasumsikan adanya pengaruh yang konstan dari error term. Penyebab heterogenitas di setiap negara diasumsikan tetap sepanjang periode penelitian. Pada uji Chow dengan menggunakan Stata 14, P Value (Prob>F) kurang dari alpha 0,05 sehingga pilihan terbaik adalah fixed effect model disbandingkan dengan pooled least square. Pada uji Hausman, $\mathrm{P}$ Value (Prob $>$ Chi2) kurang dari alpha 0,05 sehingga pilihan terbaik adalah fixed effect model daripada random effect model.

Penelitian menggunakan data investasi asing pada efek surat utang dari net incurrence of liabilities (dalam miliar dolar AS) dari IMF untuk kebutuhan data panel. Data penelitian menggunakan periode tahunan 2000-2017. Pemilihan periode mempertimbangkan ketersediaan mayoritas data dari sampel penelitian. Selain melihat aliran dana asing secara umum di emerging markets, penelitian ini khusus melihat kasus aliran dana asing ke pasar surat utang Indonesia dengan data aliran investasi yang sama. Data investasi asing pada efek surat utang dari net incurrence of liabilities 
termasuk di dalam data posisi investasi internasional pada neraca pembayaran.

Penelitian menggunakan sampel 24 emerging markets, ditambah dengan tiga negara Asia dalam kategori developed markets dan tiga negara Asia dalam kategori frontier markets berdasarkan klasifikasi MSCI pada The MSCI Global Market Accessibility Review. MSCI mengklasifikasikan negara dalam tiga kategori, yakni developed markets, emerging markets, dan frontier markets. Ada lima kriteria yang membedakan ketiga markets tersebut, yakni keterbukaan pada kepemilikan asing, kemudahan aliran dana untuk masuk atau keluar, efisiensi kerangka operasional, ketersediaan instrumen investasi, dan stabilitas kerangka institusional. Evaluasi aksesibilitas pasar global MSCI menggunakan umpan balik dari beragam partisipan di seluruh pasar keuangan, termasuk pengelola aset pasif dan aktif, pemilik aset, broker, kustodian, bursa efek, dan regulator (MSCI, 2019). Tabel 3 adalah 30 sampel negara dalam penelitian.

Variabel keterbukaan finansial menggunakan indeks KAOPEN yang dikembangkan Chinn dan Ito dengan menggunakan basis data Annual Report on Exchange Arrangements and Exchange Restrictions (AREAER) IMF (Chinn dan Ito, 2019). AREAER menyediakan deskripsi pengaturan nilai tukar, kurs, dan sistem perdagangan negara-negara anggota IMF. AREAER juga mengumpulkan informasi tentang operasi pasar nilai tukar, kontrol perdagangan internasional, kontrol transaksi modal, dan kebijakan pada sektor finansial, termasuk kebijakan kehati-hatian negara (IMF, 2019).

Asumsi dasar variabel ini adalah bahwa keterbukaan finansial yang semakin tinggi akan meningkatkan investasi asing. KAOPEN merupakan indeks dengan variabel binary dummy yang mengkodifikasi tabulasi transaksi finansial lintas negara berdasarkan AREAER (Chinn dan Ito, 2008). Variabel keterbukaan finansial menggunakan indeks KAOPEN yang dinormalisasi antara 0 dan 1 . Semakin terbuka pasar finansial suatu negara maka indeks mendekati 1 . Semakin tertutup pasar finansial, maka indeks mendekati nol.

Indeks Chinn dan Ito merupakan variabel keterbukaan finansial secara de jure. Indeks ini memiliki kelemahan, yakni tidak memiliki variasi seiring berjalannya waktu untuk beberapa negara karena kebijakan nilai tukar dan kontrol modal seringkali tidak berubah dalam jangka panjang (Okada, 2013). Sebagai contoh, hanya ada dua perubahan indeks finansial KAOPEN untuk Indonesia pada periode tahun 2000-2017. Variabel keterbukaan finansial secara de facto bisa menggunakan rasio gross capital inflow terhadap PDB dan aliran investasi asing pada World Development Indicators (Ang, 2011; Kant, 2018) meski rasio ini tidak bisa menunjukkan kebijakan kontrol modal. Karena capital inflow pada obligasi ini terkait erat dengan hitungan keterbukaan finansial secara de facto, maka penelitian ini menggunakan variabel keterbukaan finansial secara de jure. Indeks KAOPEN yang dipakai adalah indeks terkini hingga tahun 2017 yang menggunakan laporan AREAER tahun 2018.

Tabel 3

Negara Sampel Penelitian

\begin{tabular}{lll}
\hline \hline Afrika Selatan & India & Polandia \\
Arab Saudi & Indonesia & Qatar \\
Argentina & Jepang & Republik Ceko \\
Bangladesh & Kolombia & Rusia \\
Brasil & Korea & Singapura \\
Chile & Malaysia & Sri Lanka \\
China & Meksiko & Thailand \\
Filipina & Mesir & Turki \\
Hong Kong & Pakistan & Vietnam \\
Hungaria & Peru & Yunani \\
\hline
\end{tabular}

Sumber: MSCI (2019)

Variabel institution atau kelembagaan menggunakan kontrol korupsi yang merupakan satu dari enam dimensi Worldwide Governance Indicator dari Bank Dunia. Worldwide Governance Indicator melapor- 
kan enam dimensi luas tata kelola pada lebih dari 215 negara. Keenam dimensi ini adalah voice and accountability, political stability and absence of violence, government effectiveness, regulatory quality, rule of law, dan control of corruption (WorldBank, 2020). Bank Dunia mengombinasikan responden perusahaan-perusahaan, warga negara, dan ahli dalam survei di negara maju dan berkembang. Indikator ini didasarkan pada 30 sumber data individual yang dihasilkan oleh survei berbagai institusi, think tanks, organisasi non-pemerintahan, organisasi internasional, dan perusahaan sektor swasta.

Penelitian ini terutama menitikberatkan pada dimensi control of corruption atau kontrol korupsi. Indeks kontrol korupsi memiliki kisaran dari $-2,5$ yang menunjukkan kontrol korupsi paling lemah hingga 2,5 yang menunjukkan kontrol korupsi kuat. Hal yang termasuk dalam indikasi kontrol korupsi kuat adalah proses hukum dari pejabat publik yang mendapatkan keuntungan dari korupsi ringan hingga berat. Faktor kelembagaan yang lebih baik berpotensi menarik investasi asing lebih besar. Kontrol korupsi yang lebih baik berpotensi menarik investasi asing lebih besar.

Variabel human capital menggunakan data rata-rata lama tahun sekolah (mean years of school) dari Unesco Institute for Statistics (Unesco Institute for Statistics, 2019). Penggunaan proxy rata-rata lama tahun sekolah mempertimbangkan bahwa pendidikan, usia, dan sektor akan memengaruhi produktivitas pekerja yang menunjukkan variabel human capital (Lucas, 1990). Rata-rata lama tahun sekolah pada variabel ini merupakan rata-rata tahun pendidikan di suatu negara untuk penduduk berusia 25 tahun ke atas, tidak termasuk waktu tinggal kelas. Unesco mengumpulkan data dari sensus penduduk nasional serta survei rumah tangga dan angkatan kerja. Human capital yang lebih baik berpotensi menarik investasi asing lebih besar (Lucas, 1990).
Faktor determinan lokal lain yang digunakan adalah pertumbuhan PDB dan suku bunga lokal yang ditunjukkan oleh yield obligasi negara. Investor asing lebih besar kemungkinan untuk menempatkan investasi di negara-negara dengan partumbuhan ekonomi yang tinggi. Sedangkan faktor suku bunga juga berpotensi menentukan besaran investasi asing karena terkait dengan imbal hasil yang diharapkan. Data pertumbuhan PDB berasal dari Bank Dunia dan suku bunga lokal berasal dari data IMF.

Variabel harga komoditas (commodity prices) menggunakan data harga minyak dunia. Harga minyak menggunakan persentase perubahan harga minyak Brent yang berasal dari Primary Commodity Price System IMF. Harga minyak ini menunjukkan potensi beban negara, mengingat mayoritas bahan bakar masih menggunakan minyak serta potensi pendapatan bagi negara-negara dengan pendapatan minyak yang besar. Opsi penggunaan harga komoditas non-bahan bakar dilakukan untuk mempertimbangkan potensi pendapatan negara yang memiliki komoditas lain seperti pertanian, mineral, serta berbagai komoditas lain yang masuk dalam indeks non-fuel berdasarkan klasifikasi IMF.

Variabel indeks volatilitas diwakili oleh VIX Index di Chicago Board Option Exchange yang mengukur volatilitas pasar saham AS menggunakan data dari Bloomberg. Volatilitas pasar saham dan pasar keuangan berpeluang untuk memengaruhi pilihan investasi global. Jika terjadi gejolak atau volatilitas tinggi di pasar saham global, investor bisa menarik dana dari emerging markets yang dianggap lebih berisiko. Jika volatilitas pasar saham makin tinggi, maka minat investor untuk berinvestasi di aset berisiko emerging markets akan berkurang (Byrne dan Fiess, 2016). Variabel pertumbuhan ekonomi negara maju diwakili oleh Kelompok G7. Variabel ini diharapkan bisa menunjukkan faktor kekayaan dalam teori permintaan aset. Investor bisa mengalihkan dana ke negara emerging markets untuk mencari return yang 
lebih tinggi jika pertumbuhan ekonomi negara-negara maju melambat. Hal ini juga berlaku untuk yield US Treasury jangka pendek dan jangka panjang. Yield US Treasury jangka pendek dan jangka panjang internasional menggunakan yield US Treasury Bill dan US Treasury Bond dengan data dari IMF. Jika terjadi penurunan yield suku bunga di negara maju (US Treasury) maka investor akan mengalihkan portofolio ke emerging markets yang menawarkan yield lebih tinggi.

\section{ANALISIS DAN PEMBAHASAN}

Pergerakan harga dan yield US Treasury berpengaruh bagi investasi asing di emerging markets karena AS menjadi acuan pasar surat utang global. Sebagai acuan, pergerakan yield US Treasury bisa memengaruhi yield surat utang negara lain, termasuk emerging markets. Berikut adalah grafik yield US Treasury jangka pendek dan jangka panjang.

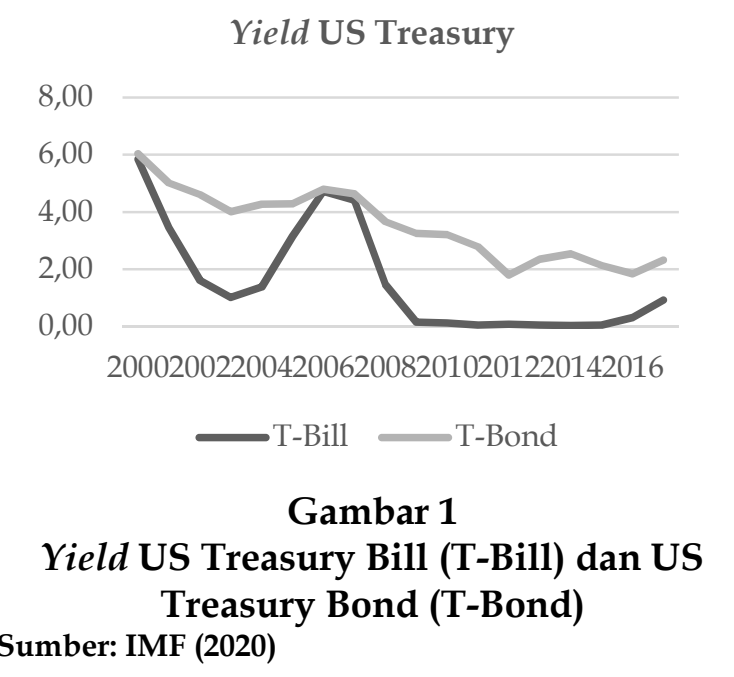

Pada gambar 1, US Treasury Bill (T-Bill) memiliki yield lebih rendah daripada US Treasury Bond (T-Bond) karena T-Bill merupakan surat utang jangka pendek yang dianggap memiliki risiko lebih kecil daripada T-Bond. Yield US Treasury jangka pendek yang lebih kecil daripada jangka panjang menunjukkan kurva yield yang mengarah ke atas (upward slope). Pada tahun 2006-2007, selisih yield T-Bill dan T-Bond menyempit dan mengarah ke inverted yield curve yang mengindikasikan resesi (Mishkin, 2019).

Kurva yield yang cenderung datar mengindikasikan bahwa suku bunga jangka pendek diperkirakan turun secara moderat (Lihat Grafik 1). Pada Desember 2008, bank sentral AS Federal Reserve menurunkan suku bunga acuan Federal Funds Rate ke level terendah, yaitu $0 \%-0,25 \%$ setelah dimulainya krisis finansial. Federal Funds Rate merupakan suku bunga acuan jangka pendek overnight unsecured untuk transaksi antarbank. Berdasarkan informasi pada Federal Reserve, level suku bunga jangka pendek ini akan memengaruhi ketersediaan dan biaya kredit di AS dan pada akhirnya keputusan ekonomi yang diambil oleh pebisnis dan rumah tangga di AS. Rekor suku bunga acuan terendah ini bertahan hingga Desember 2015. Federal Reserve baru menaikkan Federal Funds Rate secara bertahap mulai Desember 2015.

Pergerakan harga dan yield US Treasury berpengaruh bagi investasi asing di emerging markets karena AS menjadi acuan pasar surat utang global. Pacific Investment Management Company (PIMCO), perusahaan investasi global yang fokus pada investasi pendapatan tetap (fixed income) yang memiliki aset dasar (underlying asset) surat utang mengungkapkan, acuan atau benchmark yang efektif harus memenuhi kriteria tertentu. PIMCO harus memenuhi sebagian besar atau seluruh kriteria, yakni transparan, dapat diinvestasikan, memiliki harga harian, memiliki data historis, pergantian efek yang rendah, acuan dibangun sebelum ada evaluasi, dan menyatakan karakteristik risiko yang ada pada acuan (PIMCO, 2020).

US Treasury menjadi acuan karena memiliki likuiditas perdagangan yang besar. Pada akhir 2019, utang publik AS mencapai US\$23,20 triliun dengan kepemilikan publik US\$17,17 triliun dan kepemilikan intragovernmental US\$ 6,03 triliun. Data Treasury International Capital menunjukkan, investor asing memiliki total US\$ 
6,7 triliun surat utang negara AS. Dari sisi likuiditas, volume transaksi harian rata-rata US Treasury mencapai US\$ 523 miliar per hari pada Desember 2019 berdasarkan data asosiasi industri pasar modal AS, Securities Industry and Financial Markets Association (SIFMA). Informasi dan data historis US Treasury mudah diakses sehingga mengurangi potensi risiko informasi asimetri. AS juga memiliki peringkat utang di level tertinggi AAA dari berbagai lembaga rating yang menunjukkan bahwa US Treasury memiliki risiko rendah. Dengan karakteristikkarakteristik tersebut, US Treasury menjadi salah satu acuan untuk instrumen surat utang global.

Sebagai acuan, pergerakan yield US Treasury bisa memengaruhi yield surat utang negara lain, termasuk emerging markets. Menurut teori ekspektasi, obligasi memiliki karakteristik substitusi sempurna (perfect substitutes) yang berarti jika obligasi dengan tenor berbeda merupakan perfect substitute maka return obligasi-obligasi ini harus setara. Yield obligasi tenor panjang mengikuti pergerakan yield obligasi tenor pendek menyebabkan secara umum yield obligasi bergerak bersama-sama. Dalam hal ini, US Treasury yang dilihat sebagai safe haven dianggap sebagai obligasi dengan tenor pendek karena memiliki risiko lebih rendah. Sedangkan obligasi emerging markets yang memiliki risiko lebih tinggi dilihat sebagai obligasi tenor panjang. Jika suku bunga obligasi dengan tenor pendek diperkirakan naik dalam jangka panjang, maka suku bunga obligasi tenor panjang memiliki besaran sesuai ekspektasi kenaikan suku bunga jangka pendek tersebut. Ketika yield US Treasury turun, investor memperkirakan yield surat utang emerging markets pun akan ikut turun sehingga investor akan menempatkan dana ketika yield masih tinggi.

Suku bunga lokal berpotensi memengaruhi besaran investasi asing karena terkait dengan imbal hasil yang diharapkan. Variabel suku bunga lokal menggunakan yield obligasi negara. Rata-rata yield surat utang lokal dari 30 negara sampel adalah $6,41 \%$. Sedangkan median yield surat utang lokal dari negara sampel adalah 5,20\%. Rata-rata yield surat utang lokal memiliki selisih lebar dengan median karena beberapa negara memiliki yield jauh lebih tinggi.

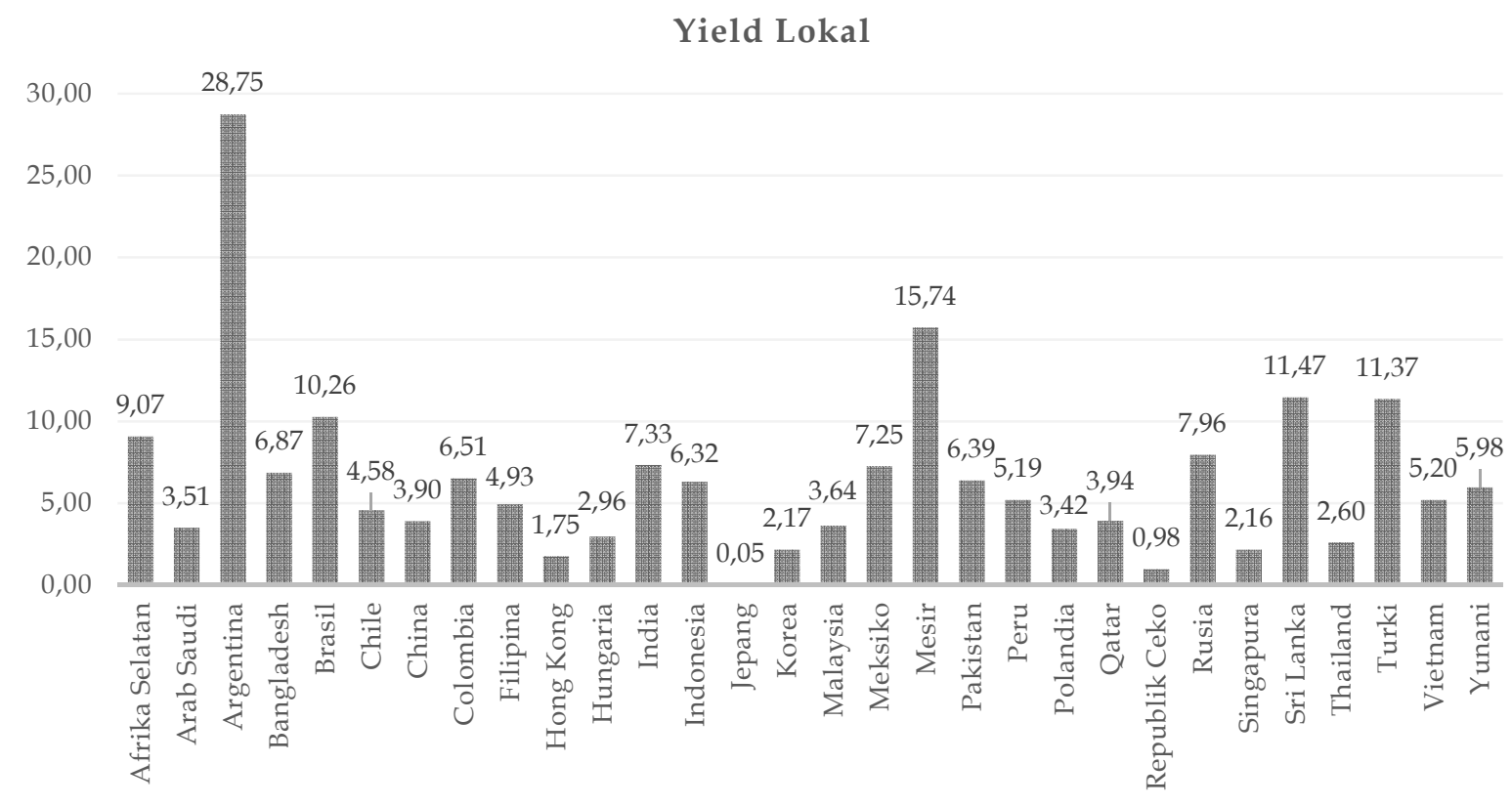

Gambar 2

Yield Surat Utang Lokal Tahun 2017

Sumber: IMF (2020) 
Pada Gambar 2 dapat kita lihat Yield tertinggi di emerging markets pada tahun 2017 adalah Argentina, yaitu 28,75\%. Argentina menghadapi krisis utang dan krisis ekonomi yang menyebabkan yield naik tinggi. Selain Argentina, negara yang memiliki yield surat utang tinggi adalah Mesir (15,74\%), Sri Lanka (11,47\%), Turki $(11,37 \%)$, Brasil (10,26\%), dan Afrika Selatan $(9,07 \%)$. Beberapa negara yang menawarkan yield tinggi adalah negara yang sedang menghadapi krisis ekonomi atau politik. Yield surat utang lokal menunjukkan return sekaligus risiko suatu negara. Yield surat utang Indonesia pada tahun 2017 berada di $6,32 \%$. Meski lebih rendah daripada ratarata yield sampel pada $6,41 \%$, yield surat utang Indonesia masih lebih tinggi daripada median sampel 5,20\%. Negara-negara yang memiliki yield surat utang terendah dari seluruh sampel adalah Jepang (0,50\%), Republik Ceko (0,98\%), dan Hong Kong $(1,75 \%)$. Sedangkan yield surat utang Indonesia pada tahun 2017 berada di 6,32\%.

Kenaikan yield disebabkan oleh penurunan harga obligasi. Ketika risiko negara meningkat karena krisis politik atau ekonomi, investor akan menghindari obligasi negara tersebut. Investor berpotensi menjual surat utang untuk menghindari risiko. Aksi penjualan surat utang ini akan menyebabkan harga obligasi turun karena penawaran lebih besar daripada permintaan. Ketika harga turun, yield obligasi meningkat karena harga dan yield bergerak berlawanan. Ketika risiko meningkat, investor akan mengharapkan ada tambahan premi risiko untuk menempatkan dana di negara tersebut sehingga yield surat utang naik.

Pertumbuhan PDB pada Gambar 3 menunjukkan potensi return yang diharapkan oleh investor di emerging markets. Ratarata pertumbuhan $\mathrm{PDB}$ dari 30 sampel negara adalah 3,76\% dan median 3,77\%. Pertum-buhan ekonomi Indonesia sebesar $5,07 \%$ pada tahun 2017. Pertumbuhan ekonomi Indonesia ini masih lebih tinggi daripada rata-rata dan median sampel penelitian. Beberapa negara yang juga memiliki partumbuhan PDB lebih dari 5\% pada tahun 2017 antara lain Bangladesh $(7,28 \%)$, China $(6,76 \%)$, Filipina $(6,68 \%)$, India $(7,17 \%)$, Malaysia $(5,74 \%)$, Pakistan $(5,55 \%)$, Turki $(7,47 \%)$, dan Vietnam $(6,81 \%)$.

Pertumbuhan PDB 2017

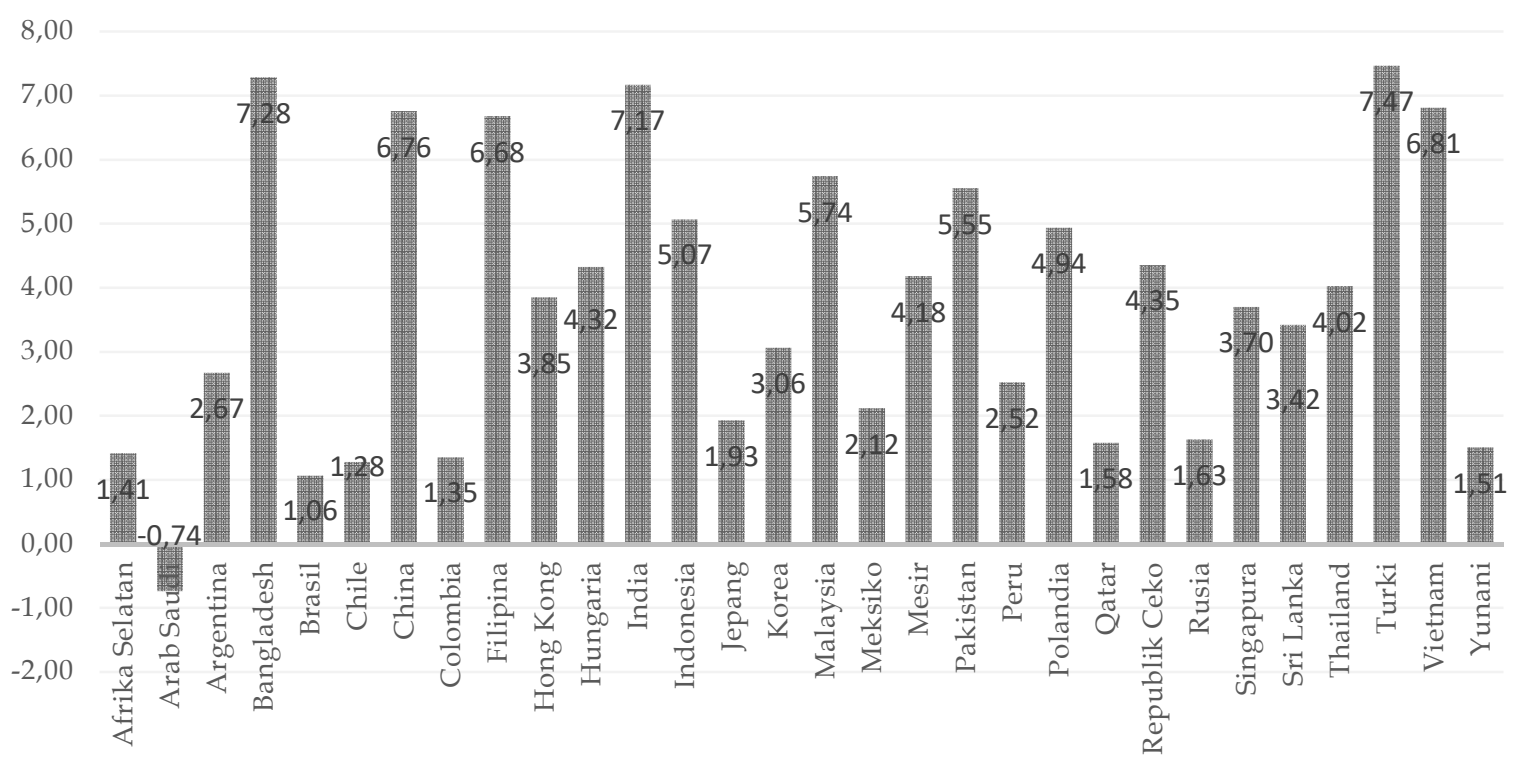

Gambar 3

Pertumbuhan PDB Tahun 2017

Sumber: Bank Dunia (2020) 
Data aliran investasi surat utang bersih secara global menggunakan data liabilitas berupa aliran bersih instrumen surat utang yang tercatat dalam net incurrence of liabilities posisi investasi internasional pada neraca pembayaran dari IMF. Nilai positif menunjukkan masuknya investasi asing dalam instrumen surat utang suatu negara. Nilai negatif menunjukkan keluar atau penurunan investasi asing pada surat utang suatu negara. Kekurangan dari penggunaan aliran bersih ini adalah bahwa besaran aliran masuk atau aliran keluar tidak diperhitungkan terpisah.

\section{Aliran Dana Asing ke Surat Utang Emerging Markets (US\$ miliar)}

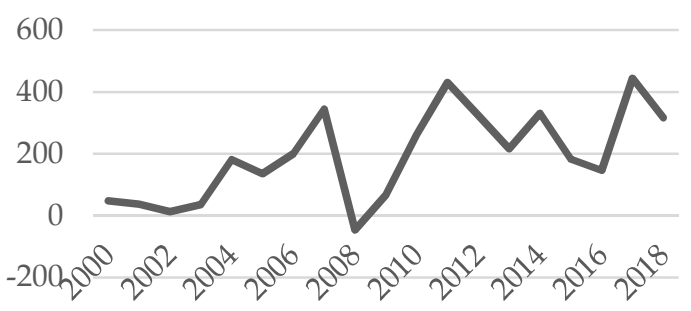

Gambar 4

Aliran Investasi Asing ke Surat Utang Emerging Markets

Sumber: IMF (2020)

Pada Gambar 4 pergerakan aliran bersih investasi asing terlihat bahwa pada tahun 2008, akumulasi aliran bersih investasi asing di 30 negara emerging markets sampel penelitian negatif. Artinya, secara total investor asing menarik dana dari emerging markets. Tahun tersebut adalah tahun krisis finansial yang berpusat di AS. Aliran investasi bersih ini sudah memperhitungkan aliran dana yang masuk dan keluar. Angka negatif menunjukkan bahwa aliran dana keluar emerging markets lebih besar daripada aliran dana yang masuk. Setelah Federal Reserve menurunkan Federal Funds Rate di akhir 2008, aliran bersih investasi asing ke emerging markets kembali positif mulai 2009.

Aliran bersih investasi asing di pasar surat utang Indonesia masih positif pada tahun 2008. Dana asing yang masuk ke surat utang Indonesia lebih besar daripada dana yang keluar meski jumlahnya menurun bila dibandingkan dengan 2005-2007. Aliran investasi bersih dana asing ke surat utang Indonesia berada dalam tren naik sejak tahun 2000 hingga 2019 sehingga kepemilikan asing pada surat utang Indonesia juga meningkat, seperti yang dapat kita lihat di Gambar 5.

\section{Aliran Dana Asing ke Surat Utang Indonesia (dalam US\$ miliar)}

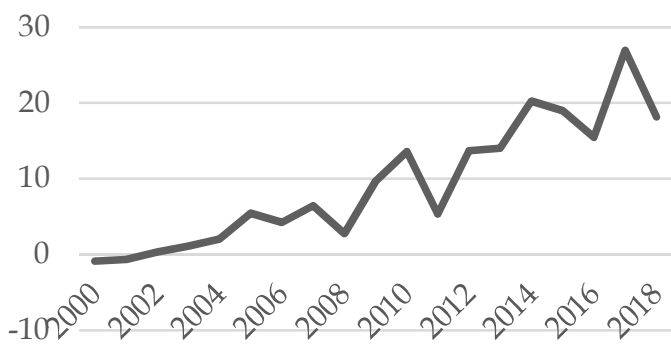

\section{Gambar 5}

Aliran Investasi Asing ke Surat Utang Indonesia

Sumber: IMF (2020)

Pada tahap pertama, penelitian melihat faktor yang memengaruhi aliran investasi surat utang di emerging markets. Pada tahap kedua, penelitian fokus pada aliran investasi asing di Indonesia. Analisis dilakukan dengan Stata 14.

Hasil regresi Tabel 4 menunjukkan ada empat variabel yang berpengaruh signifikan terhadap aliran investasi asing ke surat utang emerging markets. Pertumbuhan ekonomi emerging markets berpengaruh signifykan $(5 \%)$ pada aliran dana asing. Keterbukaan pasar finansial serta kontrol korupsi juga berpengaruh signifikan masing-masing $5 \%$ terhadap aliran investasi asing ke surat utang emerging markets. Dari faktor global, hanya perubahan suku bunga jangka panjang Amerika, US Treasury Bond yang berpengaruh negatif signifikan (10\%) terhadap aliran dana asing bersih pada investasi surat utang emerging markets. 
Tabel 4

Hasil Regresi Aliran Dana Asing di Emerging Markets

\begin{tabular}{|c|c|}
\hline & Emerging Markets \\
\hline Keterbukaan finansial & $20,6599^{* *}$ \\
\hline Kontrol korupsi & $14,7797^{* *}$ \\
\hline Human capital & 3,8644 \\
\hline$\triangle \mathrm{PDB}$ & $0,7738^{* *}$ \\
\hline Yield lokal & 0,2536 \\
\hline VIX & $-0,0034$ \\
\hline Harga komoditas & 0,0777 \\
\hline$\Delta \mathrm{PDB} G 7$ & $-0,4660$ \\
\hline Yield T-Bill & $-0,0409$ \\
\hline Yield T-Bond & $-3,5740^{*}$ \\
\hline Constant & $-37,2378$ \\
\hline F-test & $3,26^{* * *}$ \\
\hline Degrees of Freedom & 164 \\
\hline $\mathrm{R}^{2}$ & 0,4269 \\
\hline Adj $R^{2}$ & 0,2941 \\
\hline $\mathrm{N}$ & 203 \\
\hline
\end{tabular}

Level signifikan: *:10\%, **: 5\%, ***: $1 \%$

Sumber: KAOPEN, Unesco, Bank Dunia, IMF, dan Bloomberg (2020): Data diolah

Variabel global ini secara bersama-sama memengaruhi aliran investasi surat utang bersih di emerging markets dengan Prob > F yang menunjukkan angka 0,0007. Dengan angka $\mathrm{R}^{2}$ sebesar 0,4269 , variasi dari nilai dana asing bersih di instrumen surat utang emerging markets dapat dijelaskan 42,69\% oleh variasi dari nilai variabel variabel keterbukaan finansial, kontrol korupsi, human capital, yield lokal, pertumbuhan ekonomi, indeks volatilitas VIX, harga komoditas minyak, yield US Treasury Bill, yield US Treasury Bond, dan pertumbuhan ekonomi negara-negara G7.

Kenaikan $1 \%$ pertumbuhan ekonomi emerging markets berpotensi meningkatkan aliran dana asing bersih hingga US\$ 774 juta. Peningkatan keterbukaan pasar finansial $1 \%$ berpeluang menarik investasi asing hingga US\$ 20,66 miliar ke surat utang emerging markets. Kenaikan indeks kontrol korupsi sebesar 1\% akan meningkatkan aliran dana asing bersih ke emerging markets hingga US\$ 14,78 miliar. Sedangkan penurunan 1\% yield US Treasury Bond akan meningkatkan aliran investasi asing ke surat utang emerging markets hingga US\$ 3,57 miliar, ceteris paribus.

Ada perbedaan dampak variabel suku bunga dan pertumbuhan ekonomi terhadap aliran investasi bersih pada instrumen surat utang Indonesia. Dengan variabel yang sama kecuali keterbukaan finansial, aliran dana asing bersih ke surat utang justru meningkat jika pertumbuhan ekonomi dan suku bunga lokal turun. Variabel keterbukaan finansial untuk Indonesia hanya berubah satu kali pada tahun 2011 sehingga dikecualikan dalam analisis. Ada tiga variabel yang berpengaruh signifikan terhadap aliran investasi surat utang di Indonesia, yakni pertumbuhan ekonomi, yield lokal (SUN), dan kontrol korupsi.

Tabel 5

Aliran Dana Asing di Surat Utang Indonesia

\begin{tabular}{lc}
\hline \hline & \multicolumn{1}{c}{ Indonesia } \\
\hline Kontrol korupsi & $0,2525^{* *}$ \\
Human capital & 0,5903 \\
Yield lokal & $-1,9106^{*}$ \\
$\Delta$ PDB & $-8,8683^{* *}$ \\
VIX & 0,0094 \\
Harga komoditas & \\
$\Delta$ PDB G7 & $-0,3437$ \\
Yield T-Bill & \\
Yield T-Bond & 2,8744 \\
Constant & $68,5180^{* * *}$ \\
F-test & $39,61^{* * *}$ \\
R $^{2}$ & 0,8689 \\
\hline
\end{tabular}

Level signifikan: *:10\%, ${ }^{* *}: 5 \%,{ }^{* * *}: 1 \%$

Sumber: KAOPEN, Unesco, Bank Dunia, IMF, dan Bloomberg (2020): Data diolah

Hasil regresi pada Tabel 5 dengan robust standard error menunjukkan bahwa tingkat suku bunga lokal (SUN) dan pertumbuhan PDB berpengaruh negatif signifikan masing-masing $10 \%$ dan $5 \%$ terhadap aliran investasi asing bersih pada instrumen surat utang di Indonesia. 
Tabel 6

Perbandingan Variabel Emerging Markets dan Indonesia

\begin{tabular}{ll}
\hline \hline \multicolumn{1}{c}{ Emerging Markets } & \multicolumn{1}{c}{ Indonesia } \\
\hline Pertumbuhan PDB $(+)$ & Pertumbuhan PDB (-) \\
Keterbukaan finansial $(+)$ & Yield SUN $(-)$ \\
Kontrol korupsi $(+)$ & Kontrol korupsi $(+)$ \\
Yield US Treasury Bond (-) & \\
\hline Sumber: KAOPEN, Unesco, Bank Dunia, IMF, dan Bloomberg (2020): Data diolah
\end{tabular}

Penurunan yield SUN berpotensi menarik investasi asing pada surat utang Indonesia. Penurunan partum-buhan ekonomi Indonesia justru berpotensi meningkatkan aliran dana asing ke pasar SUN. Sama seperti analisis untuk emerging markets, pertumbuhan PDB per kapita tidak berpengaruh signifikan terhadap aliran investasi asing di instrumen surat utang Indonesia. Variabel kontrol korupsi pun berpengaruh signifikan (5\%) terhadap aliran modal asing ke instrumen surat utang di Indonesia. Perbaikan kontrol korupsi akan meningkatkan aliran investasi masuk bersih asing ke instrumen surat utang.

Pertumbuhan ekonomi menjadi faktor penarik investasi asing pada instrumen surat utang emerging markets. Secara umum, semakin tinggi pertumbuhan ekonomi, maka aliran dana asing akan semakin besar. Di emerging markets, variabel keterbukaan finansial dan kontrol korupsi berpengaruh signifikan terhadap aliran investasi asing di emerging markets. Dari faktor global, penurunan suku bunga US Treasury berpengaruh signifikan pada aliran dana emerging markets, seperti tersaji pada Tabel 6 .

Hasil penelitian ini sesuai dengan teori permintaan aset investasi. Pertumbuhan ekonomi menunjukkan faktor return yang diharapkan pada investasi surat utang. Variabel keterbukaan finansial menunjukkan faktor likuiditas yang diinginkan investor dalam menentukan permintaan aset. Variabel kontrol korupsi menunjukkan faktor risiko relatif terhadap aset lain. Sedangkan yield US Treasury menunjukkan return relatif terhadap aset lain. Ketika yield
US Treasury turun, investor mencari alternatif investasi lain dengan yield yang lebih besar.

Tetapi, hasil analisis untuk Indonesia menunjukkan bahwa pertumbuhan ekonomi berpengaruh negatif signifikan terhadap aliran investasi asing. Pertumbuhan ekonomi Indonesia berada di sekitar 5\% mulai periode 2013 hingga 2017, lebih rendah daripada periode 2007-2012 yang berada di atas $6 \%$. Tetapi, pada periode setelah 2013, aliran dana asing ke surat utang Indonesia membesar. Pada angka 5\%, pertumbuhan ekonomi Indonesia masih lebih baik daripada rata-rata pertumbuhan ekonomi global. Indonesia pun mendapatkan peringkat investment grade pertama kali dari Fitch Ratings pada Desember 2011. Moody's menaikkan peringkat utang Indonesia ke level investment grade pada Januari 2012. Sedangkan S\&P menempatkan Indonesia di peringkat investment grade pada Mei 2017. Perbaikan peringkat utang ini berarti lembaga pemeringkat menilai risiko Indonesia mengecil daripada periode-periode sebelumnya.

Level investment grade menjadi salah satu syarat kehati-hatian investasi bagi investor internasional seperti manajer investasi, dana pensiun, dan berbagai pengelola dana. Oleh karena itu, permin-taan surat utang Indonesia bisa meningkat ketika ada perbaikan rating. Peningkatan permintaan surat berharga di Indonesia menyebabkan harga obligasi naik dan yield turun. Yield SUN Indonesia setelah pening-katan peringkat investment grade lebih rendah daripada periode hingga 2009 yang masih double digit 
meski masih lebih tinggi daripada median yield emerging markets dalam penelitian. Hal ini menunjukkan suku bunga lokal berpengaruh negatif signifikan terhadap aliran investasi asing di Indonesia.

Tabel 7

Perbandingan Yield dan PDB Indonesia dan Emerging Markets Tahun 2017

\begin{tabular}{lrr}
\hline \hline & Yield & \multicolumn{1}{c}{$\boldsymbol{\Delta}$ PDB } \\
\hline Rata-rata & $6,41 \%$ & $3,76 \%$ \\
Median & $5,20 \%$ & $3,77 \%$ \\
Indonesia & $6,32 \%$ & $5,07 \%$ \\
\hline
\end{tabular}

Sumber: Bank Dunia, IMF, diolah (2020)

Pada tabel 7, jika dibandingkan dengan rata-rata negara sampel lain dalam penelitian untuk emerging markets, pertumbuhan PDB Indonesia masih jauh lebih tinggi di akhir periode penelitian tahun 2017, yaitu 5,07\% dibandingkan dengan rata-rata $3,76 \%$ dan median $3,77 \%$. Sedangkan suku bunga (yield) SUN Indonesia sebesar 6,32\% di akhir tahun 2017, lebih tinggi daripada median yield obligasi negara-negara emerging markets dalam sampel sebesar 5,20\%. Yield SUN Indonesia lebih rendah daripada rata-rata yield surat utang emerging markets karena ada beberapa negara yang memiliki yield surat utang sangat tinggi akibat adanya krisis ekonomi dan politik seperti Argentina $(28,75 \%)$, Mesir $(18,08 \%)$, dan Turki $(17,36 \%)$.

Perbedaan hasil antara pengaruh pertumbuhan PDB dan suku bunga terhadap aliran investasi obligasi di emerging markets dan Indonesia disebabkan oleh kondisi pertumbuhan ekonomi dan suku bunga Indonesia yang lebih tinggi jika dibandingkan dengan negara-negara emerging markets. Pertumbuhan ekonomi Indonesia yang lebih rendah dalam beberapa tahun terakhir jika dibandingkan dengan periode antara 2000-2013 juga menimbulkan asumsi bahwa Indonesia perlu mencari pendanaan eksternal untuk kebutuhan anggaran sehingga investor masuk ke instrumen surat utang Indonesia. Yield surat utang Indonesia yang lebih tinggi menarik investasi asing sehingga investor mau menempatkan dana di Indonesia. Kedua hal ini meningkatkan permintaan instrumen investasi SUN sehingga harga surat utang meningkat. Kenaikan harga surat utang ini menyebabkan yield SUN turun sehingga pada periode penelitian, yield SUN Indonesia semakin rendah.

Hasil penelitian ini sesuai dengan teori permintaan aset. Penurunan yield US Treasury Bond serta suku bunga lokal mencerminkan return yang diinginkan oleh investor. Ketika yield US Treasury turun, investor akan mencari aset yang memberikan imbal hasil atau return yang lebih tinggi. Meski suku bunga Indonesia berpengaruh negatif, tetapi Indonesia masih memberikan yield yang lebih tinggi jika dibandingkan dengan negara-negara emerging markets. Selain itu, selisih antara yield US Treasury Bond dan SUN masih lebar dan menguntungkan. Pertumbuhan PDB negara tujuan juga menunjukkan faktor return yang diharapkan oleh investor. Variabel kontrol korupsi menunjukkan tingkat risiko yang bersedia ditanggung oleh investor. Kontrol korupsi yang tinggi menunjukkan risiko yang lebih rendah dalam berinvestasi sehingga bisa meningkatkan permintaan aset.

\section{SIMPULAN DAN SARAN Simpulan}

Faktor yang memengaruhi investasi asing pada surat utang emerging markets adalah keterbukaan finansial, kontrol korupsi, pertumbuhan PDB, dan penurunan yield US Treasury Bond. Keterbukaan finansial menunjukkan faktor likuiditas yang memengaruhi minat investasi asing pada surat utang. Kontrol korupsi menunjukkan faktor risiko yang dipertimbangkan oleh investor. Pertumbuhan PDB dan yield US Treasury Bond mewakili potensi return yang diharapkan oleh investor. 
Faktor yang memengaruhi investasi asing pada surat utang Indonesia adalah kontrol korupsi yang menunjukkan faktor risiko, pertumbuhan PDB yang menunjukkan faktor return, dan yield SUN yang menunjukkan faktor risiko sekaligus return. Pertumbuhan ekonomi dan yield surat utang Indonesia relatif lebih tinggi daripada emerging markets sehingga aliran investasi asing pada surat utang Indonesia masih meningkat meski pertumbuhan PDB dan yield SUN turun.

\section{Saran}

Pemerintah perlu meningkatkan penegakan hukum terhadap korupsi dan keterbukaan pasar finansial untuk bisa setara dengan negara-negara emerging markets lain. Karena suku bunga SUN justru berpengaruh negatif signifikan, pemerintah tidak perlu menawarkan suku bunga yang terlalu tinggi. Pemerintah juga tidak perlu menerbitkan surat utang secara besarbesaran ketika yield turun, karena bunga surat utang akan tetap menjadi beban bagi APBN. Selain itu, peningkatan suplai surat utang yang besar akan menurunkan harga yang sekaligus bisa menaikkan yield SUN.

Penelitian ini memiliki keterbatasan yakni penggunaan pertumbuhan PDB sebagai proxy faktor kekayaan dalam permintaan aset. Perlu penelitian lebih lanjut mengenai asal dana investasi di Indonesia, misalnya dari pengelola dana seperti hedge fund, fund manager, dana pensiun, dan asuransi global. Selain itu, penggunaan proxy indeks KAOPEN membatasi adanya variabel keterbukaan finansial Indonesia sehingga perlu proxy keterbukaan finansial lain.

\section{DAFTAR PUSTAKA}

Ahmed, S. dan A. Zlate. 2014. Capital Flows to Emerging Market Economies: A Brave New World? Journal of International Money and Finance 48: 221248.

Aizenman, J. dan G. K. Pasricha. 2013. Why do Emerging Markets Liberalize
Capital Outflow Controls? Fiscal Versus Net Capital Flow Concerns. Journal of International Money and Finance 39: 28-64.

Ammer, J., S. Claessens, A. Tabova, dan C. Wroblewski. 2019. Home Country Interest Rates and International Investment in U.S. Bonds. Journal of International Money and Finance 95: 212-227.

Ang, J. B. 2011. Financial Development, Liberalization and Technological Deepening. European Economic Review 55(5): 688-701.

Anggitawati, D. dan I. A. Ekaputra. 2018. Foreign Portfolio Investment Flows and Exchange Rate: Evidence in Indonesia. Emerging Markets Finance dan Trade: 1-15.

Baharumshah, A. Z., L. Slesman, dan E. S. Devadason. 2017. Types of Foreign Capital Inflows and Economic Growth: New Evidence on Role of Financial Markets. Journal of International Development 29: 768-789.

Belgibayeva, A. dan A. Plekhanov. 2019. Does Corruption Matter for Sources of Foreign Direct Investment? Review of World Economics 155: 487-510.

Beltran, D. O., M. Kretchmer, J. Marquez, dan C. P. Thomas. 2013. Foreign Holdings of U.S. Treasuries and U.S. Treasury Yields. Journal of International Money and Finance 32: 11201143.

Bostanci, G. dan K. Yilmaz. 2020. How Connected is the Global Sovereign Credit Risk Network? Journal of Banking and Finance 113.

Broto, C., J. Diaz-Cassou, dan A. Erce. 2011. Measuring and Explaining the Volatility of Capital Flows to Emerging Countries. Journal of Banking dan Finance 35: 1941-1953.

Byrne, J. P. dan N. Fiess. 2016. International Capital Flows to Emerging Markets: National and Global Determinants. Journal of International Money and Finance 61: 82-100. 
Caporale, G. M., F. Menla Ali, F. Spagnolo, dan N. Spagnolo. 2017. International Portfolio Flows and Exchange Rate Volatility in Emerging Asian Markets. Journal of International Money and Finance 76: 1-15.

Cerutti, E., S. Claessens, dan D. Puy. 2019. Push Factors and Capital Flows to Emerging Markets: Why Knowing Your Lender Matters More Than Fundamentals. Journal of International Economics 119: 133-149.

Chinn, M. D. dan H. Ito. 2008. A New Measure of Financial Openness. Journal of Comparative Policy Analysis 10(3): 309-322.

Chinn, M. D. dan H. Ito. 2019. The Chinn-Ito Index. http://web.pdx.edu/ ito/ChinnIto_website.htm.

Combes, J.-L., T. Kinda, dan P. Plane. 2012. Capital Flows, Exchange Rate Flexibility, and the Real Exchange Rate. Journal of Macroeconomics 34: 1034-1043.

Ebeke, C. dan Y. Lu. 2015. Emerging Market Local Currency Bond Yields and Foreign Holdings - A Fortune or Misfortune? Journal of International Money and Finance 59: 203-219.

Farhi, E. dan I. Werning. 2014. Dilemma Not Trilemma? Capital Controls and Exchange Rates with Volatile Capital Flows. IMF Economic Review (62): 569-605.

Ferreira, M. A., P. Matos, J. P. Pereira, dan P. Pires. 2017. Do Locals Know Better? A Comparison of the Performance of Local and Foreign Institutional Investors. Journal of Banking and Finance 82: 151-164.

Garg, R. dan P. Dua. 2014. Foreign Portfolio Investment Flows to India: Determinants and Analysis. World Development 59: 16-28.

Hlaing, S. W. dan M. Kakinaka. 2019. Global Uncertainty and Capital Flows: Any Difference Between Foreign Direct Investment and Portfolio Invest- ment? Applied Economics Letters 26(3): 202-209.

IMF. 2019. Annual Report on Exchange Arrangements and Exchange Restrictions 2018. Washington DC: International Monetary Fund.

Jain, P. K., E. Kuvvet, dan M. S. Pagano. 2017. Corruption's Impact of Foreign Portfolio Investment. International Business Review 26: 23-35.

Jayasuriya, S. dan S. Leu. 2017. Volatile Capital Flows and Macroeconomic Performance in Indonesia: An SVAR Analysis. Economic Papers 36(2): 135155.

Jehan, Z. dan A. Hamid. 2017. Exchange Rate Volatility and Capital Inflow: Role of Financial Development. Portuguese Economic Journal 16: 189203.

Kant, C. 2018. Financial Openness dan Institutions in Developing Countries. Research in International Business and Finance 46: 240-250.

Kinda, T. 2012. On the Drivers of FDI and Portfolio Investment: A Simultaneous Equations Approach. International Economic Journal 26(1): 1-22.

Kitano, S. dan K. Takaku. 2018. Capital Controls, Monetary Policy, dan Balance Sheets in a Small Open Economy. Economic Inquiry 56(2): 859874.

Kodongo, O. dan K. Ojah. 2012. The Dynamic Relation Between Foreign Exchange Rates and International Portfolio Flows: Evidence from Africa's Capital Markets. International Review of Economics and Finance 24: 71-87.

Kolokolova, O., M.-T. Lin, dan S.-H. Poon. 2020. Too Big to Ignore? Hedge Fund Flows and Bond Yields. Journal of Banking and Finance 112 (March 2020).

Konopczak, K. dan M. Konopczak. 2017. Impact of International Capital Flows on Emerging Markets' Sovereign Risk Premium - Demand 
vs Vulnerability Effect. Finance Research Letters 23: 239-245.

Körner, F. M. dan H.-M. Trautwein. 2015. Sovereign Credit Ratings and the Transnationalization of Finance Evidence from a Gravity Model of Portfolio Investment. Economics: The Open-Access, Open-Assessment EJournal 9: 1-54.

Lucas, R. E. 1990. Why Doesn't Capital Flow from Rich to Poor Countries? The American Economic Review 80(2): 9296.

Mankiw, N. G. 2013. Macroeconomics. Worth Publishers. New York.

Markowitz, H. 1952. Portfolio Selection. The Journal of Finance 7(1): 77-91.

Melo-Becerra, A., J. E. Ramos-Forero, dan H. Zarate-Solano. 2015. Sovereign Bond Markets and Financial Stability in an Emerging Economy: An Aplication of Directed Acyclic Graphs and SVAR Models. Macroeconomics and Finance in Emerging Market Economies 8(3): 306-319.

Mishkin, F. S. 2019. The Economics of Money, Banking, and Financial Markets, 12th Edition. Pearson Education. New York.

MSCI. 2019. MSCI Global Market Accessibility Review. https://www. msci.com/documents/1296102/1330218/ MSCI_Global_Market_Accessibilty_Re view_June_2019.pdf/511b8357-58a54992-3774-47f60baa1505.

Musibau, H. O., A. H. Yusuf, dan K. L. Gold. 2019. Endogenous Specification of Foreign Capital Inflows, Human Capital Development and Economic Growth. International Journal of Social Economics 46(3): 454-472.

Okada, K. 2013. The Interaction Effects of Financial Openness and Institutions on International Capital Flows. Journal of Macroeconomics 35: 131-143.

Olani, A. 2020. Dynamic Effecst of Macroeconomic Policies on Categories of Emerging Markets' Capital Inflows. Macroeconomics and Finance in Emerging Market Economies 13(1): $1-28$.

Pandolfi, L. dan T. Williams. 2019. Capital Flows and Sovereign Debt Markets: Evidence from Index Rebalancings. Journal of Financial Economics 132: 384-403.

Patrino, P. 2020. Fitch Ratings. https://www. fitchratings.com/research/fund-assetmanagers/ratings-definitions-26-032020.

Pham, T. H. 2015. China's Sovereign Bond Yield: Some Lessons. Applied Economics Letters 22(3): 223-227.

PIMCO. 2020. Benchmarks. https://global. pimco.com/en-gbl/resources/education/ understanding-benchmarks.

Qureshi, M. S. dan N. Sugawara. 2018. Surges and Reversals in Capital Flows. International Review of Economics and Finance 56: 92-98.

Sanya, O. dan S. M. Olanrewaju. 2015. Macroeconomic Determinants of Investment Decision in Nigeria: ISLM-BP-RP Approach. IOSR Journal of Economics and Finance 6(4): 68-74.

Sarno, L., I. Tsiakas, dan B. Ulloa. 2016. What Drives International Portfolio Flows? Journal of International Money and Finance 60: 53-72.

Tsaurai, K. 2017. Is Foreign Portfolio Equity Investment Inspired Growth Hypothesis Relevant in Emerging Markets? Euro Economica 2(36): 78-90.

Unesco Institute for Statistics. 2019. Retrieved from Unesco Institute for Statistics: http://data.uis.unesco.org/.

Vo, X. V., D. P. Nguyen, V. T. Ho, dan N. T. Thong. 2017. Where do the Advanced Countries Invest? An Investigation of Capital Flows from Advanced Countries to Emerging Economies. Journal of International Financial Markets, Institutions dan Money 51: 142-154.

WorldBank. 2020. Worldwide Governance Indicators. http://info.worldbank.org/ governance/wgi/. 
202 Ekuitas: Jurnal Ekonomi dan Keuangan - Volume 5, Nomor 2, Juni 2021 : 120 - 202

Yan, C. 2018. Hot Money in Disaggregated Capital Flows. The European Journal of Finance 24(14): 1190-1223.

Yi, J., S. Meng, C. D. Macaulay, dan M. W. Peng. 2019. Corruption and Foreign Direct Investment Phases: The Moderating Role of Institutions. Journal of International Business Policy 2: 167-181.
Yun, J. 2019. Bond Risk Premia in a Small Open Economy with Volatile Capital Flows: The Case of Korea. Journal of International Money and Finance 93: 223-243. 